\title{
Effect of liming on the magnesium status of some mineral soils and on the fate of fertilizer magnesium
}

\author{
RAILI JOKINEN \\ University of Helsinki, Department of Agricultural Chemistry, SF-00710 Helsinki 71, \\ Finland.
}

Abstract: Nine mineral soils were incubated in laboratory without lime $\left(\mathrm{Ca}_{0}\right)$ or limed $\left(\mathrm{Ca}_{1}\right)$ with calcium carbonate (lab.reag.), and without magnesium fertilizer $\left(\mathrm{Mg}_{0}\right)$ or fertilized with $\mathrm{MgSO}_{4} \cdot 7 \mathrm{H}_{2} \mathrm{O}\left(\mathrm{Mg}_{1}=4\right.$ $\mathrm{mg} / 100 \mathrm{~g}$ soil $\mathrm{Mg}$ ). The incubation covered a period of seven weeks in aerobic conditions at constant $20{ }^{\circ} \mathrm{C}$ temperature.

The relative increase in the effective cation exchange capacity (ECEC) caused by liming seemed to be in coarse mineral soils greater than in clay soils. The differences in $\mathrm{pH}\left(\mathrm{CaCl}_{2}\right)$ values between soil types was not so evident.

In seven soils of the nine, liming decreased the $0,01 \mathrm{M} \mathrm{CaCl}_{2}$ extractable magnesium content more than in $1 \mathrm{M} \mathrm{KCl}$ or in $1 \mathrm{M}$ neutral ammonium acetate extractable magnesium contents. The limed soils contained ammonium acetate extractable magnesium 2-24\% less than the unlimed soils. The decrease in magnesium content was greatest in acid muddy silt (Littorina soil) and in acid silty clay. Without lime the $1 \mathrm{M} \mathrm{KCl}$ extractable $(\mathrm{Al}+\mathrm{H})$ contents of these soils were 6,6 and $2,2 \mathrm{me} / 100 \mathrm{~g}$ soil and $\mathrm{pH}\left(\mathrm{CaCl}_{2}\right) 3,9$ and 4,5 , respectively. In finesand soils liming seemed to increase the magnesium content although not significantly.

In limed soils $17-73 \%$ of the fertilizer magnesium was extractable in $0,01 \mathrm{M} \mathrm{CaCl}_{2}, 67-100 \%$ extractable in $1 \mathrm{M} \mathrm{KCl}$ and $57-100 \%$ extractable in $1 \mathrm{M}$ neutral ammonium acetate.

The equivalent ratio of exchangeable (1 M ammonium acetate, $\mathrm{pH} 7$ ) calcium to magnesium in the ioils may give pointers to the choice of liming agents, especially in the liming of low cation exchange capacity soils.

\section{Introduction}

In a pot experiment ryegrass took up magnesium from nine mineral soils less than the exchangeable ( $1 \mathrm{M}$ neutral ammonium acetate) magnesium content of the soils decreased during the experiment (JOKINEN 1981 a, b). A possible explanation for the decrease in the soil magnesium content might be the fixation by liming of soil magnesium to forms not extractable in ammonium acetate (ADAMS and HENDERSON 1962, CHRISTENSON et al. 1973, KAILA 1974, JUO and UZU 1977).

The purpose of this incubation experiment was to elaborate the effects of liming on the magnesium status of the nine mineral soils used as growth base in the pot experiment. The fertilizer magnesium was also the object of research. 
Table 1. Some properties of soils at start of incubation experiment.

\begin{tabular}{|c|c|c|c|c|c|c|c|c|c|}
\hline & $\begin{array}{l}1 \\
\text { Fine- } \\
\text { sand }\end{array}$ & $\begin{array}{l}2 \\
\text { Fine- } \\
\text { sand }\end{array}$ & $\begin{array}{c}3 \\
\text { Very } \\
\text { fine- } \\
\text { sand }\end{array}$ & $\begin{array}{c}4 \\
\text { Muddy } \\
\text { silt }\end{array}$ & $\begin{array}{c}5 \\
\text { Silty } \\
\text { clay }\end{array}$ & $\begin{array}{c}6 \\
\text { Sandy } \\
\text { clay }\end{array}$ & $\begin{array}{c}7 \\
\text { Sandy } \\
\text { clay }\end{array}$ & $\begin{array}{c}8 \\
\text { Silty } \\
\text { clay }\end{array}$ & $\begin{array}{c}9 \\
\text { Heavy } \\
\text { day }\end{array}$ \\
\hline $\mathrm{pH}\left(\mathrm{CaCl}_{2}\right)$ & 4,4 & 5,1 & 5,0 & 3,9 & 4,5 & 5,6 & 5,0 & 6,1 & 5,6 \\
\hline Org. C $\%$ & 1,9 & 4,7 & 3,0 & 6,1 & 5,7 & 4,5 & 5,6 & 2,8 & 5,2 \\
\hline Clay \% ( $0,002 \mathrm{~mm})$ & 4,4 & 4,5 & 11,7 & 25,4 & 30,9 & 36,4 & 43,8 & 45,1 & 64,3 \\
\hline Silt $\%(0,002-0,020 \mathrm{~mm})$ & 7,2 & 15,4 & 42,3 & 40,4 & 55,0 & 41,0 & 24,5 & 42,9 & 13,8 \\
\hline $\begin{array}{l}\text { Effective } \mathrm{CEC} \text { me } / 100 \mathrm{~g} \text { soil } \\
\text { Exchangeable } \\
(1 \mathrm{M} \text { ammonium acetate, } \mathrm{pH} 7)\end{array}$ & 3,0 & 7,8 & 5,7 & 9,6 & 9,4 & 14,8 & 15,6 & 19,7 & 23,9 \\
\hline $\begin{array}{l}\mathrm{Ca}^{2+} \mathrm{me} / 100 \mathrm{~g} \text { soil } \\
\mathrm{Mg}^{2+} \\
\mathrm{K}^{+}\end{array}$ & $\begin{array}{l}1,09 \\
0,11 \\
0,24\end{array}$ & $\begin{array}{l}6,86 \\
0,57 \\
0,32\end{array}$ & $\begin{array}{l}3,75 \\
1,25 \\
0,18\end{array}$ & $\begin{array}{l}2,99 \\
0,55 \\
0,38\end{array}$ & $\begin{array}{l}6,61 \\
1,00 \\
0,51\end{array}$ & $\begin{array}{r}14,13 \\
1,95 \\
1,13\end{array}$ & $\begin{array}{r}11,39 \\
4,30 \\
0,59\end{array}$ & $\begin{array}{r}18.58 \\
2,80 \\
0.77\end{array}$ & $\begin{array}{r}18.71 \\
6,53 \\
1.5\end{array}$ \\
\hline $\begin{array}{l}0,01 \mathrm{M} \mathrm{CaCl}_{2} \text { extract. } \mathrm{Mg} \\
\mathrm{mg} / 100 \mathrm{~g} \text { soil } \\
1 \mathrm{M} \mathrm{KCl} \text { extract. } \mathrm{Mg} \\
\mathrm{mg} / 100 \mathrm{~g} \text { soil } \\
1 \mathrm{M} \mathrm{KCl} \text { extract. }(\mathrm{Al}+\mathrm{H}) \\
\mathrm{me} / 100 \mathrm{~g} \text { soil }\end{array}$ & 1,21 & 4,53 & 15,06 & 4,53 & 11,36 & 21,23 & 50,06 & 17,75 & 40,25 \\
\hline
\end{tabular}

\section{Materials and methods}

The incubation experiment was carried out with nine mineral soils. Detailed information of the properties of these soils was presented in the report concerning the magnesium uptake by ryegrass in pot experiment (JOKINEN $1981 \mathrm{~b}$ ). The $\mathrm{pH}$ $\left(\mathrm{CaCl}_{2}\right)$ of the soils varied from 3,9 to 6,1 and the ammonium acetate $(1 \mathrm{M}, \mathrm{pH} 7)$ extractable magnesium content from 0,11 to $6,53 \mathrm{me} / 100 \mathrm{~g}$ soil (Table 1 ).

The moist soils were air-dryed and crushed in a mortar to pass a $2 \mathrm{~mm}$ sieve.

For the incubation experiment $200 \mathrm{~g}$ soil was weighed in plastic bags (volume $1 / 2$ litre). The soils were treated with calcium carbonate (lab. reag.) and magnesium sulphate $\left(\mathrm{MgSO}_{4} \cdot 7 \mathrm{H}_{2} \mathrm{O}\right.$, p.a.), and the amounts of calcium and magnesium per $100 \mathrm{~g}$ soil were as follows:

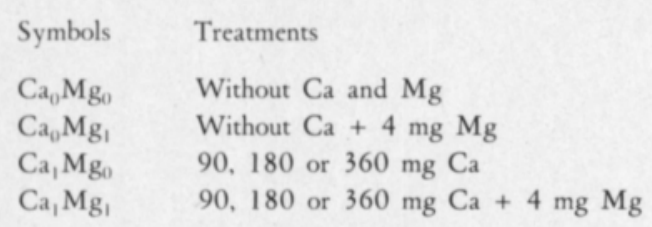

The aim of the liming was to raise the $\mathrm{pH}$ of the soils to between 6 and 6,5 . Because of the differences in the initial $\mathrm{pH}$ values of the soils it was necessary to give unequal amounts of lime. The amounts of calcium per $100 \mathrm{~g}$ soil were as follows:

$90 \mathrm{mg} \mathrm{Ca}$ : Finesand (2), very finesand, sandy clay (6) and silty clay (8)

$180 \mathrm{mg} \mathrm{Ca}$ : Finesand (1), silty clay (5), sandy clay (7) and heavy clay

$360 \mathrm{mg}$ Ca: Muddy silt

The treatments were replicated four times and the total number of pots amounted to 144 . 
The soils were moistened with de-ionized water to $60 \%$ of the field capacity. The bags were provided with covers full of holes and incubation took place during seven weeks in a room of constant temperature of $20^{\circ} \mathrm{C}$. During this time the moisture of the soils was checked every week and de-ionized water was applied if necessary.

After incubation the soils were left to dry to air-dry state, and crushing and sieving were performed as before the incubation.

For description of the soil magnesium status three extractants were used: 1) l M neutral ammonium acetate is common in determination of the exchangeable magnesium, 2) $1 \mathrm{M} \mathrm{KCl}$ extracts magnesium in the original $\mathrm{pH}$ of the soil, 3) $0,01 \mathrm{M}$ $\mathrm{CaCl}_{2}$ is used to describe the magnesium activity in soil. The extracting power of $\mathrm{NH}_{4}{ }^{+}$and $\mathrm{K}+$ should be the same, but the difference is in the buffering ability of the solutions. The soil analysis was performed with the same methods as with the soils of the pot experiment (JOKINEN 1981 b) to determine neutral ammonium acetate extractable calcium, magnesium, potassium and sodium contents, $1 \mathrm{M} \mathrm{KCl}$ extractable magnesium, aluminium and hydrogen contents and effective cation exchange capacity, $0,01 \mathrm{M} \mathrm{CaCl}_{2}$ extractable magnesium content and $\mathrm{pH}$.

The statistical treatments were performed by means of analysis of variance and the differences between soil treatments by Duncan's new multiple range test. In the tables the results on the same line provided with the same letter do not deviate significantly $(\mathrm{P}=0,05 \%)$.

\section{Results}

After the incubation the $\mathrm{pH}$ of almost all soils was near the set target $(6,0-$ $6,5)$; in finesand (2) the $\mathrm{pH}$ was somewhat bolow and in silty clay (8) above it.

Liming increased significantly the effective cation exchange capacity of the soils (Table 2). In coarse mineral soils and in acid silty clay (5) the relative increase in effective cation exchange capacity seemed to be greater than in clay soils within the uniform calcium supply. The relative increases in ECEC and absolute increases in $\mathrm{pH}$ caused by liming $\left(\mathrm{Ca}_{1}-\mathrm{Ca}_{0}\right)$ were as follows:

$\begin{array}{cc}\text { Relative } & \begin{array}{c}\text { Absolute } \\ \text { increase }\end{array} \\ \text { increase } \\ \text { in ECEC, } \% & \text { in } \mathrm{pH}\left(\mathrm{CaCl}_{2}\right)\end{array}$

2. Finesand

3. Very finesand

6. Sandy clay

8. Silty clay

1. Finesand

5. Silty clay

7. Sandy clay

9. Heavy clay 
Table 2. The $\mathrm{pH}\left(\mathrm{CaCl}_{2}\right), 1 \mathrm{M} \mathrm{KCl}$ extractable $(\mathrm{Al}+\mathrm{H})$ content and effective cation exchange capacity ECEC (me/100 g soil) of the soils after incubation.

\begin{tabular}{|c|c|c|c|c|}
\hline & $\mathrm{Ca}_{0} \mathrm{Mg}_{0}$ & $\mathrm{Ca}_{0} \mathrm{Mg}_{1}$ & $\mathrm{Ca}_{1} \mathrm{Mg}_{0}$ & $\mathrm{Ca}_{1} \mathrm{Mg}_{1}$ \\
\hline & \multicolumn{4}{|c|}{$\mathrm{pH}\left(\mathrm{CaCl}_{2}\right)$} \\
\hline 1. Finesand & $4,4^{\mathrm{a}}$ & $4,4^{a^{2}}$ & $6,4^{\mathrm{b}}$ & $6,7^{c}$ \\
\hline 2. Finesand & $5,0^{\mathrm{a}}$ & $5,0^{a}$ & $5,8^{b}$ & $5,9^{\mathrm{c}}$ \\
\hline 3. Very finesand & $5,1^{b}$ & $5,0^{\mathrm{a}}$ & $6,2^{\mathrm{c}}$ & $6,2^{\mathrm{c}}$ \\
\hline 4. Muddy silt & $4,0^{\mathrm{a}}$ & $4,0^{\mathrm{a}}$ & $6,2^{b}$ & $6,2^{b}$ \\
\hline 5. Silty clay & $4,5^{\mathrm{a}}$ & $4.5^{\mathrm{a}}$ & $6,3^{b}$ & $6,2^{b}$ \\
\hline 6. Sandy clay & $5,5^{a}$ & $5,5^{\mathrm{a}}$ & $6,4^{b}$ & $6.4^{b}$ \\
\hline 7. Sandy clay & $5,0^{\mathrm{a}}$ & $5,1^{b}$ & $6,4^{c}$ & $6,5^{\mathrm{d}}$ \\
\hline 8. Silty clay & $6,2^{a}$ & $6,2^{\mathrm{a}}$ & $6,9^{b}$ & $7,0^{c}$ \\
\hline \multirow[t]{2}{*}{ 9. Heavy clay } & $5,3^{\mathrm{a}}$ & $5,3^{\mathrm{a}}$ & $6,6^{b}$ & $6,6^{b}$ \\
\hline & \multicolumn{4}{|c|}{$(\mathrm{Al}+\mathrm{H}) \mathrm{me} / 100 \mathrm{~g}$ soil } \\
\hline 1. Finesand & $1,82^{b}$ & $1,85^{b}$ & $0,21^{\mathrm{a}}$ & $0,15^{\mathrm{a}}$ \\
\hline 2. Finesand & $0,59^{b}$ & $0,59^{b}$ & $0,26^{\mathrm{a}}$ & $0,21^{\mathrm{a}}$ \\
\hline 3. Very finesand & $0,86^{b}$ & $0,82^{b}$ & $0,18^{\mathrm{a}}$ & $0,22^{\mathrm{a}}$ \\
\hline 4. Muddy silt & $5,87^{c}$ & $5,94^{\mathrm{C}}$ & $0,31^{\mathrm{a}}$ & $0,55^{b}$ \\
\hline 5. Silty clay & $1,92^{\mathrm{b}}$ & $1,93^{b}$ & $0,20^{\mathrm{a}}$ & $0,16^{\mathrm{a}}$ \\
\hline 6. Sandy clay & $0,35^{b}$ & $0,36^{b}$ & $0,17^{\mathrm{a}}$ & $0,19^{a}$ \\
\hline 7. Sandy clay & $0,64^{\mathrm{d}}$ & $0,60^{c}$ & $0,25^{b}$ & $0,22^{\mathrm{a}}$ \\
\hline 8. Silty clay & $0,28^{b}$ & $0,26^{b}$ & $0,19^{\mathrm{a}}$ & $0,15^{a}$ \\
\hline \multirow[t]{2}{*}{ 9. Heavy clay } & $0,32^{\mathrm{a}}$ & $0,33^{\mathrm{a}}$ & $0,28^{\mathrm{a}}$ & $0,25^{\mathrm{a}}$ \\
\hline & \multicolumn{4}{|c|}{ ECEC $\mathrm{me} / 100 \mathrm{~g}$ soil } \\
\hline 1. Finesand & $2,9^{\mathrm{a}}$ & $3,3^{\mathrm{a}}$ & $8,4^{b}$ & $8,7^{b}$ \\
\hline 2. Finesand & $7,5^{\mathrm{a}}$ & $8,1^{b}$ & $10,6^{\mathrm{c}}$ & $11,2^{\mathrm{d}}$ \\
\hline 3. Very finesand & $5,7^{\mathrm{a}}$ & $6,0^{b}$ & $9,1^{\mathrm{c}}$ & $9,3^{\mathrm{d}}$ \\
\hline 4. Muddy silt & $8,9^{\mathrm{a}}$ & $9,2^{\mathrm{a}}$ & $19.4^{b}$ & $19,7^{b}$ \\
\hline 5. Silty clay & $8,6^{\mathrm{a}}$ & $9,0^{\mathrm{a}}$ & $15,1^{b}$ & $15,1^{b}$ \\
\hline 6. Sandy clay & $15,5^{\mathrm{a}}$ & $16,0^{\mathrm{a}}$ & $18,5^{b}$ & $19,2^{b}$ \\
\hline 7. Sandy clay & $15,4^{\mathrm{a}}$ & $15,8^{\mathrm{a}}$ & $21,9^{b}$ & $22,4^{b}$ \\
\hline 8. Silty clay & $20,3^{a}$ & $20,7^{a}$ & $22,7^{b}$ & $23,1^{\mathrm{C}}$ \\
\hline 9. Heavy clay & $24,0^{\mathrm{a}}$ & $24,2^{\mathrm{a}}$ & $31,8^{b}$ & $32,2^{\mathrm{b}}$ \\
\hline
\end{tabular}

Magnesium fertilization had only slight effect on either the ECEC or on the $\mathrm{pH}$ of the soils.

There was no aluminium in sandy clay (6), silty clay (8) and heavy clay extractable in $\mathrm{KCl}(\mathrm{lM})$ and therefore the results in Table 2 expressing the $(\mathrm{Al}+\mathrm{H})$ contents indicate the amounts of hydrogen in these soils. In muddy silt the aluminium content amounted to $65 \%$ of the $(\mathrm{Al}+\mathrm{H})$ content, in other soils either the content of aluminium and hydrogen was equal (silty clay 5 ) or the aluminium content was less than that of hydrogen.

Because of liming the $(\mathrm{Al}+\mathrm{H})$ content of all soils decreased significantly except in heavy clay. From limed soils $\mathrm{KCl}$ extracted only hydrogen. Magnesium fertilization increased significantly the $(\mathrm{Al}+\mathrm{H})$ content in muddy silt.

The $\mathrm{KCl}(\mathrm{l} \mathrm{M})$ extractable magnesium content in all untreated incubated soils was $88-98 \%$ of the magnesium extractable in ammonium acetate (1 M, pH 7, Table 3). In muddy silt the $\mathrm{KCl}$ extractable magnesium amounted to $78 \%$ respectively. 
Table 3. Magnesium content $(\mathrm{mg} / 100 \mathrm{~g})$ of the soils extractable in $1 \mathrm{M}$ neutral ammonium acetate, in $1 \mathrm{M} \mathrm{KCl}$ and in $0,01 \mathrm{M} \mathrm{CaCl}_{2}$ after incubation.

\begin{tabular}{|c|c|c|c|c|}
\hline & $\mathrm{Ca}_{0} \mathrm{Mg}_{0}$ & $\mathrm{Ca}_{0} \mathrm{Mg}_{\mathrm{I}}$ & $\mathrm{Ca}_{1} \mathrm{Mg}_{0}$ & $\mathrm{Ca}_{1} \mathrm{Mg}_{1}$ \\
\hline & \multicolumn{4}{|c|}{$1 \mathrm{M}$ neutral ammonium acetate } \\
\hline 1. Finesand & $1,23^{\mathrm{a}}$ & $5,54^{\mathrm{c}}$ & $1,26^{\mathrm{a}}$ & $4,46^{\mathrm{b}}$ \\
\hline 2. Finesand & $5,86^{\mathrm{a}}$ & $10,40^{\mathrm{b}}$ & $6,02^{a}$ & $11,06^{\mathrm{b}}$ \\
\hline 3. Very finesand & $15,99^{\mathrm{b}}$ & $19,83^{\mathrm{d}}$ & $15,18^{\mathrm{a}}$ & $19,11^{\mathrm{C}}$ \\
\hline 4. Muddy silt & $6,15^{b}$ & $10,11^{\mathrm{d}}$ & $4,68^{a}$ & $8,00^{\mathrm{c}}$ \\
\hline 5. Silty day & $10,88^{b}$ & $14,81^{\mathrm{d}}$ & $9,20^{\mathrm{a}}$ & $11,90^{\mathrm{c}}$ \\
\hline 6. Sandy clay & $24,26^{\mathrm{a}}$ & $28,95^{\mathrm{b}}$ & $23,74^{\mathrm{a}}$ & $26,84^{b}$ \\
\hline 7. Sandy clay & $50,26^{\mathrm{b}}$ & $54,62^{\mathrm{c}}$ & $46,67^{a}$ & $48,98^{b}$ \\
\hline 8. Silty clay & $34,48^{b}$ & $38,92^{\mathrm{d}}$ & $31,78^{\mathrm{a}}$ & $35,95^{\mathrm{C}}$ \\
\hline \multirow[t]{2}{*}{ 9. Heavy clay } & $76,96^{b}$ & $83,08^{\mathrm{c}}$ & $72,56^{a}$ & $76,15^{b}$ \\
\hline & \multicolumn{4}{|c|}{$1 \mathrm{M} \mathrm{KCl}$} \\
\hline 1. Finesand & $1,24^{\mathrm{a}}$ & $5,20^{\mathrm{C}}$ & $1,17^{a}$ & $4,25^{\mathrm{b}}$ \\
\hline 2. Finesand & $5,75^{\mathrm{a}}$ & $9,66^{b}$ & $5,62^{a}$ & $9,23^{b}$ \\
\hline 3. Very finesand & $14,62^{\mathrm{a}}$ & $18,74^{\mathrm{c}}$ & $14,18^{a}$ & $17,72^{\mathrm{b}}$ \\
\hline 4. Muddy silt & $4.81^{\mathrm{a}}$ & $8,49^{c}$ & $4,39^{a}$ & $7,20^{\mathrm{b}}$ \\
\hline 5. Silty clay & $9,58^{b}$ & $13,48^{\mathrm{d}}$ & $8,10^{\mathrm{a}}$ & $10,80^{c}$ \\
\hline 6. Sandy clay & $23,45^{\mathrm{a}}$ & $26,96^{b}$ & $22.53^{\mathrm{a}}$ & $26,08^{b}$ \\
\hline 7. Sandy day & $47,85^{b}$ & $50,88^{\mathrm{c}}$ & $46,08^{a}$ & $48,86^{b}$ \\
\hline 8. Silty clay & $31,64^{\mathrm{c}}$ & $35,82^{\mathrm{d}}$ & $27,09^{\mathrm{a}}$ & $29,75^{b}$ \\
\hline 9. Heavy clay & $74,18^{\mathrm{c}}$ & $77,97 \mathrm{~d}$ & $68,10^{\mathrm{a}}$ & $72,40^{\mathrm{d}}$ \\
\hline \multicolumn{5}{|c|}{$0,01 \mathrm{M} \mathrm{CaCl}_{2}$} \\
\hline 1. Finesand & $1,26^{\mathrm{a}}$ & $4,64^{\mathrm{C}}$ & $0,94^{a}$ & $3.48^{\mathrm{b}}$ \\
\hline 2. Finesand & $4.54^{\mathrm{a}}$ & $7,72^{\mathrm{b}}$ & $4,69^{\mathrm{a}}$ & $7,50^{\mathrm{b}}$ \\
\hline 3. Very finesand & $12,94^{b}$ & $16,22^{\mathrm{d}}$ & $11,60^{a}$ & $14.53^{\mathrm{C}}$ \\
\hline 4. Muddy silt & $4,50^{\mathrm{b}}$ & $8,06^{\mathrm{d}}$ & $3.01^{\mathrm{a}}$ & $5,51^{\mathrm{c}}$ \\
\hline 5. Silty clay & $9,18^{\mathrm{c}}$ & $12.10^{\mathrm{d}}$ & $6,4 i^{a}$ & $8.50^{\mathrm{b}}$ \\
\hline 6. Sandy clay & $14,22^{\mathrm{b}}$ & $16,63^{\mathrm{d}}$ & $12,60^{\mathrm{a}}$ & $15,00^{\mathrm{c}}$ \\
\hline 7. Sandy clay & $31,51^{b c}$ & $34,31^{\mathrm{c}}$ & $27,19^{a}$ & $28,62^{\mathrm{ab}}$ \\
\hline 8. Silty day & $17,32^{\mathrm{c}}$ & $19.63^{\mathrm{d}}$ & $14,60^{\mathrm{a}}$ & $15,29^{\mathrm{b}}$ \\
\hline 9. Heavy clay & $42,10^{c}$ & $44.75^{\mathrm{d}}$ & $33,75^{\mathrm{a}}$ & $36,50^{\mathrm{b}}$ \\
\hline
\end{tabular}

From the clay soils $0,01 \mathrm{M} \mathrm{CaCl}_{2}$ seemed to extract to a noticeably smaller degree magnesium than ammonium acetate. In comparison to ammonium acetate the extracting ability of $\mathrm{CaCl}_{2}$ was perhaps somewhat greater in coarse mineral soils $(1-4)$ and acid silty clay $(5)$ than in clay soils (6-9).

Without magnesium fertilization most of the limed soils contained significantly smaller amounts of ammonium acetate extractable magnesium than the unlimed soils (Table 3 ). The absolute decrease in soil magnesium content caused by liming was greatest in sandy clay (7) $3,6 \mathrm{mg} / 100 \mathrm{~g}$ and heavy clay $4,4 \mathrm{mg} / 100 \mathrm{~g}$. In relative terms, the greatest decrease in the soil magnesium content by liming was observed in muddy silt $(24 \%)$ and in acid silty clay (15\%). In contradistinction to other soils liming seemed to increase to a slight degree the ammonium acetate extractable magnesium content in finesand soils.

Liming decreased significantly the amount of $1 \mathrm{M} \mathrm{KCl}$ extractable magnesium in silty clays ( 5 and 8$)$, sandy clays ( 6 and 7$)$ and heavy clay. The relative decrease in the magnesium content was greatest in sandy ciays, $15 \%$ and $14 \%$, respectively. 
It should be noted that liming seemed to have no effect on the $\mathrm{KCl}$ extactable magnesium content of muddy silt, although the amount of ammonium acetate extractable magnesium decreased significantly.

In all soils the $\mathrm{CaCl}_{2}$ extractable magnesium content decreased by liming more than the magnesium extractable in $\mathrm{KCl}$ or ammonium acetate. In muddy silt and acid silty clay the magnesium content $\left(\mathrm{CaCl}_{2}\right)$ was $38 \%$ and $30 \%$ lower in limed than in unlimed soils. The relative decrease in the ammonium acetate extractable magnesium caused by liming was also greatest in these two soils.

Almost all the fertilizer magnesium $(4 \mathrm{mg} / 100 \mathrm{~g}$ soil $)$ was extractable in ammonium acetate in unlimed soils, yet the magnesium content of heavy clay increased more than by the magnesium supply. The $\mathrm{KCl}$ extractable magnesium increased in nearly all soils with the same amount as the given magnesium, with the exception of sandy clays. In coarse mineral soils $3,1-3,6 \mathrm{mg} / 100 \mathrm{~g}$ of the fertilizer magnesium extracted in $\mathrm{CaCl}_{2}$ and in clay soils $2,3-2,9 \mathrm{mg} / 100 \mathrm{~g}$.

Liming also caused the fixation of fertilizer magnesium in the forms not extractable in ammonium acetate. This was most intense in acid silty clay and sandy clays and weaker in finesand (1), muddy silt and heavy clay. The exchangeable magnesium content of limed sandy clay (7) and heavy clay supplied with magnesium was the same as the magnesium content of untreated soils. Magnesium fertilization seemed to cover the decrease in soil magnesium content caused by liming in these soils. In the other soils magnesium fertilization increased significantly the exchangeable magnesium.

In muddy silt, silty clays and sandy clay (7) liming caused about $30 \%$ of fertilizer magnesium to be fixed in forms not extractable in $\mathrm{KCl}$, in other soils the respective figures varied from 7 to $20 \%$. The $\mathrm{KCl}$ extractable magnesium content of silty clay (8) and heavy clay was significantly lower when supplied with lime and magnesium than without treatments.

The $\mathrm{CaCl}_{2}$ extractable magnesium content of silty clay (8) increased by magnesium fertilization only $0,7 \mathrm{mg} / 100 \mathrm{~g}$ and the content of sandy clay (7) 1,4 $\mathrm{mg} / 100 \mathrm{~g}$ soil. The respective increase in other soils amounted to $2,1-2,9 \mathrm{mg} / 100$ $\mathrm{g}$ soil. After incubation, 17-73\% of the magnesium in limed soils applied in fertilization was extractable in $\mathrm{CaCl}_{2}$. To limed silty clays and heavy clay, magnesium fertilization did not bring so much magnesium that the $\mathrm{CaCl}_{2}$ extractable magnesium would have remained at the same level as in unlimed soils.

The ammonium acetate extractable calcium content increased in all soils with nearly the amount of calcium supplied in lime (Table 4). All the calcium extracted in ammonium acetate might not come from the soil, but a part could be extracted from calcium carbonate, since the incubation continued only seven weeks. Magnesium fertilization had no effect on the calcium content of limed or of unlimed soils.

Liming decreased significantly the ammonium acetate extractable potassium content of the soil with the exception the finesands (Table 4). In the last mentioned soils the potassium content seemed to increase, as was the case also with the magnesium content. In comparison to the potassium content of unlimed soils the relative decrease was greatest in heavy clay, $6,3 \%$, and in acid silty clay, 2,2 \%.

The ammonium acetate extractable sodium content seemed to increase significantly in all limed soils (Table 4) The relative increase amounted to $3-30 \%$, in finesand (1) the sodium content could increase as much as threefold. 
Table 4. Ammonium acetate ( $1 \mathrm{M}, \mathrm{pH} 7)$ extractable calcium, potassium and sodium contents $(\mathrm{mg} / 100 \mathrm{~g}$ soil) and the equivalent ratio $\mathrm{Ca} / \mathrm{Mg}$ (ammonium acetate extractable) in the soils after incubation.

\begin{tabular}{|c|c|c|c|c|}
\hline & $\mathrm{Ca}_{0} \mathrm{Mg}_{\mathrm{O}}$ & $\mathrm{Ca}_{0} \mathrm{Mg}_{\mathrm{I}}$ & $\mathrm{Ca}_{1} \mathrm{Mg}_{0}$ & $\mathrm{Ca}_{1} \mathrm{Mg}_{1}$ \\
\hline & \multicolumn{4}{|c|}{$\mathrm{Ca} \mathrm{mg} / 100 \mathrm{~g}$ soil } \\
\hline 1. Finesand & $20^{a}$ & $23^{a}$ & $187^{b}$ & $184^{\mathrm{b}}$ \\
\hline 2. Finesand & $131^{\mathrm{a}}$ & $134^{a}$ & $217^{b}$ & $216^{b}$ \\
\hline 3. Very finesand & $79^{b}$ & $75^{a}$ & $167^{c}$ & $169^{c}$ \\
\hline 4. Muddy silt & $58^{\mathrm{a}}$ & $59^{a}$ & $404^{b}$ & $397^{b}$ \\
\hline 5. Silty clay & $127^{a}$ & $130^{\mathrm{a}}$ & $309^{b}$ & $310^{\mathrm{b}}$ \\
\hline 6. Sandy clay & $293^{a}$ & $294^{a}$ & $371^{b}$ & $372^{\mathrm{b}}$ \\
\hline 7. Sandy clay & $230^{\mathrm{a}}$ & $227^{a}$ & $391^{b}$ & $399^{b}$ \\
\hline 8. Silty clay & $380^{a}$ & $382^{\mathrm{a}}$ & $473^{b}$ & $480^{\mathrm{b}}$ \\
\hline \multirow[t]{2}{*}{ 9. Heavy clay } & $371^{a}$ & $373^{a}$ & $570^{b}$ & $556^{b}$ \\
\hline & \multicolumn{4}{|c|}{$\mathrm{K} \mathrm{mg} / 100 \mathrm{~g}$ soil } \\
\hline 1. Finesand & $9.4^{\mathrm{a}}$ & $10,2^{\mathrm{a}}$ & $10,1^{\mathrm{a}}$ & $10,0^{\mathrm{a}}$ \\
\hline 2. Finesand & $12,5^{\mathrm{a}}$ & $12,5^{\mathrm{a}}$ & $12,8^{\mathrm{a}}$ & $13,7^{\mathrm{b}}$ \\
\hline 3. Very finesand & $7,2^{b}$ & $7,3^{\mathrm{b}}$ & $6.9^{a}$ & $6,9^{a}$ \\
\hline 4. Muddy silt & $14,7^{b}$ & $15,2^{\mathrm{C}}$ & $14,3^{\mathrm{a}}$ & $13,9^{\mathrm{a}}$ \\
\hline 5. Silty clay & $18,2^{\mathrm{b}}$ & $18,3^{\mathrm{b}}$ & $17,8^{\mathrm{a}}$ & $17,8^{\mathrm{a}}$ \\
\hline 6. Sandy clay & $43,9^{\mathrm{ab}}$ & $43,9^{\mathrm{ab}}$ & $42,4^{\mathrm{a}}$ & $44,5^{\mathrm{b}}$ \\
\hline 7. Sandy clay & $23,0^{\mathrm{b}}$ & $22,9^{b}$ & $21,8^{\mathrm{a}}$ & $21,9^{\mathrm{a}}$ \\
\hline 8. Silty clay & $29,6^{\mathrm{b}}$ & $29,6^{b}$ & $28,6^{\mathrm{a}}$ & $28,1^{a}$ \\
\hline \multirow{2}{*}{ 9. Heavy clay } & $44,6^{\mathrm{d}}$ & $44,0^{c}$ & $41,8^{b}$ & $40,7^{a}$ \\
\hline & \multicolumn{4}{|c|}{$\mathrm{Na} \mathrm{mg} / 100 \mathrm{~g}$ soil } \\
\hline 1. Finesand & $0,8^{\mathrm{a}}$ & $1,1^{\mathrm{a}}$ & $2,5^{b}$ & $2.4^{b}$ \\
\hline 2. Finesand & $3,7^{\mathrm{a}}$ & $3,6^{\mathrm{a}}$ & $4,6^{\mathrm{a}}$ & $4,7^{a}$ \\
\hline 3. Very finesand & $3,0^{\mathrm{a}}$ & $2,9^{\mathrm{a}}$ & $3,6^{\mathrm{b}}$ & $3,5^{\mathrm{b}}$ \\
\hline 4. Muddy silt & $5,1^{\mathrm{a}}$ & $4,8^{\mathrm{a}}$ & $6,9^{b}$ & $6,9^{b}$ \\
\hline 5. Silty clay & $2,5^{a}$ & $2,5^{\mathrm{a}}$ & $3,3^{b}$ & $3,2^{\mathrm{b}}$ \\
\hline 6. Sandy clay & $5,4^{a}$ & $5,4^{\mathrm{a}}$ & $6,5^{b}$ & $6,4^{b}$ \\
\hline 7. Sandy clay & $5, i^{-}$ & $5,3^{a}$ & $6,5^{b}$ & $6,4^{b}$ \\
\hline 8. Silty clay & $4,9^{\mathrm{a}}$ & $4,9^{\mathrm{a}}$ & $5,9^{\mathrm{b}}$ & $6,0^{\mathrm{b}}$ \\
\hline \multirow[t]{2}{*}{ 9. Heavy clay } & $17.6^{b}$ & $17,2^{\mathrm{a}}$ & $18,1^{\mathrm{c}}$ & $17,8^{b}$ \\
\hline & \multicolumn{4}{|c|}{$\mathrm{Ca} / \mathrm{Mg}$} \\
\hline 1. Finesand & $9,8^{b}$ & $2,4^{a}$ & $90,8^{\mathrm{d}}$ & $25,0^{\mathrm{C}}$ \\
\hline 2. Finesand & $13,5 \mathrm{c}$ & $7,8^{\mathrm{a}}$ & $21,8^{\mathrm{d}}$ & $11,9^{b}$ \\
\hline 3. Very finesand & $2,9^{b}$ & $2,4^{a}$ & $6,7^{\mathrm{d}}$ & $5,4^{\mathrm{c}}$ \\
\hline 4. Muddy silt & $5,7^{b}$ & $3,5^{\mathrm{a}}$ & $52,7^{\mathrm{d}}$ & $30,0^{\mathrm{C}}$ \\
\hline 5. Silty clay & $7,1^{b}$ & $5,2^{\mathrm{a}}$ & $20,4^{\mathrm{d}}$ & $15,3^{\mathrm{C}}$ \\
\hline 6. Sandy clay & $7,4^{b}$ & $5,9^{\mathrm{a}}$ & $9.5^{\mathrm{d}}$ & $8,5^{\mathrm{c}}$ \\
\hline 7. Sandy clay & $2,8^{b}$ & $2,5^{a}$ & $5,1^{\mathrm{c}}$ & $4,9^{\mathrm{C}}$ \\
\hline 8. Silty clay & $6,7^{b}$ & $6,0^{\mathrm{a}}$ & $9.1^{\mathrm{d}}$ & $8,1^{\mathrm{c}}$ \\
\hline 9. Heavy clay & $2,9^{\mathrm{a}}$ & $2,8^{\mathrm{a}}$ & $4,8^{\mathrm{C}}$ & $4,4^{b}$ \\
\hline
\end{tabular}

The ideal estimate for the equivalent ratio of the ammonium acetate extractable calcium to magnesium may be about $5-8$. In the untreated soils of this experiment that ratio was high in finesands, and the ratio was low in very finesand, sandy clay (7) and heavy clay. The amount of calcium carbonate that increased the $\mathrm{pH}$ of the soils close to 6 increased the ratio $\mathrm{Ca} / \mathrm{Mg}$ also to a very high level especially in some coarse mineral soils (Table 4). The ratio of calcium to magnesium in lime and 
magnesium fertilizer was too low to prevent the great increase in the ratio $\mathrm{Ca} / \mathrm{Mg}$ of these soils.

The very finesand, sandy clay (7) and heavy clay favoured the calcium carbonate supply, since the equivalent ratio $\mathrm{Ca} / \mathrm{Mg}$ was initially low. In sandy clay (6) and silty clay (8) the ratio continued to stay on the ideal range, when the ratio $\mathrm{Ca} / \mathrm{Mg}$ in calcium and magnesium supplies was about 13 , the same as in this experiment. For these soils the applicability of liming agents containing 3-5 \% magnesium might prove suitable. The finesands may benefit the supply of dolomitic limestones with about $10 \%$ magnesium. To muddy silt and acid silty clay the dolomitic limestone containing 7-10\% magnesium may bring so much calcium and magnesium that the equivalent ratio could not become too high.

\section{Discussion}

In the clay soils $0,01 \mathrm{M} \mathrm{CaCl}_{2}$ extractable magnesium amounted to about a half of the ammonium acetate ( $1 \mathrm{M}, \mathrm{pH} 7)$ extractable magnesium content. In the coarse mineral soils and in the acid silty clay, resembling coarse mineral soils, a large proportion of the ammonium acetate extractable magnesium seemed to be extractable in $\mathrm{CaCl}_{2}$ as well. According to WELTE et al. (1960) and FARINA et al. (1980 a) $\mathrm{CaCl}_{2}$ extracts in relation to ammonium acetate less magnesium from the soils characterized by a higher cation exchange capacity than from soils with low cation exchange capacity.

The $1 \mathrm{M} \mathrm{KCl}$ extracted less magnesium from acid muddy silt and silty clay than ammonium acetate ( $1 \mathrm{M}, \mathrm{pH} \mathrm{7)}$, although the soils were washed with both solutions in the same way. The reasons for this difference are unknown and will be considered in additional research. In acid soils some of the exchangeable magnesium may be tight on the exchange sites.

During incubation some of the fertilizer magnesium in unlimed soils had fixed to not extractable in $0,01 \mathrm{M} \mathrm{CaCl}_{2}$, while on the other hand ammonium acetate and $\mathrm{KCl}$ extracted almost all the magnesium supplied. MOKWUNYE and MELSTED (1974) found in the soils of temperate and tropical origins that less than $10 \%$ of the added magnesium was retained in forms of not extractable in neutral ammonium acetate during 30 days incubation. In a pot experiment performed with the soils of this incubation experiment it was noted that $5-28 \%$ of the fertilizer magnesium was fixed in ammonium acetate not extractable in unlimed very fineasand and silty clays (JOKINEN 1981 b). During a two-year pot experiment the changes in the soil magnesium status may be different than in an incubation experiment of seven weeks.

Liming decreased most of all the $\mathrm{CaCl}_{2}$ extractable magnesium content of the soils, likewise the ammonium acetate extractable magnesium content decreased in nearly all soils. The results of FARINA et al. (1980 a) in a pot experiment with nine acid mineral soils seemed to indicate something to this effect in this incubation experiment. Among others WIKLANDER (1960) and VELEZ et al. (1974) found that the magnesium concentration of the soil solution or the water extractable magnesium content of the soils decreased sharper than the exchangeable magnesium content in limed soils. WIKLANDER (1960) is of the opinion that in 
limed soils some of the magnesium in soil solution may be dislocated so as to become exchangeable.

The relative decrease in the ammonium acetate extractable magnesium content caused by liming seemed to be most intense in soils with a low $\mathrm{pH}$ and an abundance in $1 \mathrm{M} \mathrm{KCl}$ extractable aluminium. Liming decreased the aluminium content of the soils likewise (HELYAR and ANDERSON 1974, FARINA et al. 1980 a). The reactions between aluminium and magnesium in the soil by raising the $\mathrm{pH}$ have been explained in various ways. KINNIBURGH et al. (1976) found freshly precipitated aluminium gels to adsorbe magnesium specifically above $\mathrm{pH} 6,5$ and they assumed that adsorbed magnesium substituted for aluminium in octahedral layer of minerals. According to $\mathrm{CHAN}$ et al. (1979) the specific adsorption of magnesium on aluminium oxides or on silicic oxides is possible, since magnesium is able to form $\mathrm{MgOH}^{+}$-ions whereas calcium can not form respective ion. The adsorbed magnesium is in an exchangeable form below pH 6 and non-exchangeable above this $\mathrm{pH}$ value. The formation of $\mathrm{Al}-\mathrm{Mg}$ compounds not ectractable in neutral ammonium acetate at a high $\mathrm{pH}$ may take place in limed soils (HUNSAKER and PRATT 1970 ) or the formation of ammonium magnesium phosphates in soils with high magnesium content may also cause the decrease of the soil magnesium content (TAYLOR et al. 1965). The high iron content of the soil does not affect the magnesium, since iron oxides do not adsorb magnesium specifically (KINNIBURGH et al. 1976).

The fixation of magnesium not extractable in neutral ammonium acetate took place likewise in soils of a low content in $\mathrm{KCl}$ extractable aluminium. From this FARINA et al. (1980 a) concluded that the aluminium resources of soil not extractable in $\mathrm{KCl}$ also participate in the specific adsorption of magnesium above $\mathrm{pH} 6$.

The decrease in the exchangeable magnesium content of the soil may have a beneficial effect on the magnesium status i.. soils with high magnesium resources in that leaching will be avoided (EDEMEADES and JUDD 1980). In soils of low magnesium content the magnesium fixation caused by liming is obvious. With magnesium containing liming agents it is possible to improve the magnesium status of soils provided that the magnesium supplied in this way does not get into fixation. The fate of magnesium carried by the liming agents needs further research work.

In the finesand soils liming seemed to increase the neutral ammonium acetate extractable magnesium, potassium and sodium contents, however, the effect of liming was not significant in all cases. These results show a different trend than the effect of liming in the other soils. As to the magnesium content of the finesand soils the results of the incubation experiment confirm those of the pot experiment (JOKINEN 1981 b). According to ALSTON (1966) liming might increase the exchangeable magnesium content of acid coarse mineral soils. The observations of EDMEADES and JUDD (1980) in nine soils yield similar evidence. WIKLANDER (1960) notes that above $\mathrm{pH} 6$ magnesium desoption takes place in the soil, since the ability of hydrogen ions to displace fixed magnesium increases.

Most of the fertilizer magnesium (43\%) was in neutral ammonium acetate in a not extractable form in limed sandy clay. In the pot experiment about $30 \%$ of the magnesium supply had been fixed in ammonium acetate not extrable in this soil (JOKINEN $1981 \mathrm{~b}$ ) and the apparent recovery of fertilizer magnesium by ryegrass was only $13 \%$ (JOKINEN 1981 a). 
In the incubation experiment the relative change of fertilizer magnesium to being not extractable in ammonium acetate was less than in the pot experiment. This may indicate that the effects of liming on the properties of the soils are slow. In muddy silt the results of the pot experiment as well as of the incubation experiment strengthened each other best of all.

The fixation caused by liming of the soil and of the fertilizer magnesium to being not extractable in neutral ammonium acetate, does not in all cases decrease the plants growth and the nutrient contents of the yield (MUNNS and FOX 1976, FARINA et al. 1980 b, JAAKKOLA and JOKINEN 1980). The reason for this lies to some extent in the fact that the plants may be able to take up some of the not very soluble sources of the soil magnesium (KAILA and KETTUNEN 1973). The yield losses are possible on coarse mineral soils e.g. when intensive agriculture with great amounts of nitrogen fertilizers is carried out (JOKINEN 1981 a).

The liming requirement on the basis of the soil $\mathrm{pH}$ has been recommended e.g. by MÄNTYLAHTI and YLÄRANTA (1980). From the results of this incubation experiment and also from those of the pot experiment (JOKINEN $1981 \mathrm{~b}$ ) it is possible to draw the conclusion that in some soils an exclusive knowledge of the liming rates is not enough. The equivalent ratio of the neutral ammonium acetate extractable calcium and magnesium in the soil may indicate the choice of the type of liming agents. In clay soils the equivalent ratios $\mathrm{Ca} / \mathrm{Mg}$ are in general lower than the ideal values $5-8$. Therefore these soils are more in need of calcium than of magnesium (KERÄNEN and JOKINEN 1964), and the applicability of calcitic limestone may be good. The decrease of the exchangeable magnesium content in the soil should be taken into consideration in the selection of liming agents for soils with low magnesium content and with low cation exchange capacity. The liming agent should contain all the more magnesium the higher the ratio $\mathrm{Ca} / \mathrm{Mg}$ in the soil.

Acknowledgement: I am grateful to the Foundation for Research of Kemira Oy for having received a grant for the completion of this research.

\section{References}

ADAMS, F. \& HENDERSON, J. B. 1962. Magnesium availability as affected by deficient and adequate levels of potassium and lime. Soil Sci. Soc. Amer. Proc. 26: 65-68.

ALSTON, A. M. 1966. The influence of $\mathrm{N}$ and $\mathrm{Mg}$ fertilizers and $\mathrm{CaCO}_{3}$ on the absorpsion of $\mathrm{Mg}$ by oats. J. Agric. Sci. 66: 61-66.

CHAN, K. Y., DAVEY, B. G. \& GEERING, H. R. 1979. Adsorption of magnesium and calcium by a soil with variable charge. Soil Sci. Soc. Amer. J. 43: 301-304.

CHRISTENSON, D. R., WHITE, R. P. \& DOLL, E. C. 1973. Yield and magnesium uptake by plants as affected by soil $\mathrm{pH}$ and calcium levels. Agron. J. 65: 205-206.

EDMEADES, D. C. \& JUDD, M. J. 1980. The effects of lime on the magnesium status and equilibria in some New Zealand topsoils. Soil Sci. 129: 156-161.

FARINA, M. P. W., SUMNER, M. E., PLANK, C.O. \& LETZSCH, W. S. 1980 a. Effect of pH on soil magnesium and its absorption by corn. Comm. Soil Sci. Plant Anal. 11: 981-992.

-, SUMMER, M. E., PLANK, C.O. \& LETZSCH, W. S. 1980 b. Exchangeable aluminium and pH as indicators of lime requirement for corn. Soil Sci. Soc. Amer. J. 44: 1036-1041.

HELYAR, K. R. \& ANDERSON, A. J. 1974. Effects of calcium carbonate on the availability of nutrients in an acid soil. Soil Sci. Soc. Amer. Proc. 38: 341-346. 
HUNSAKER, V. E. \& PRATT, P. E. 1970. The formation of mixed magnesium-aluminium hydroxides in soil materials. Soil Sci. Soc. Amer. Proc. 34: 813-816.

JAAKKOLA, A. \& JOKINEN, R. 1980. Comparison of fine and coarse limestones in pot and field experiments. Ann. Agric. Fenn. 19: 108-124.

JOKINEN, R. 1981 a. Soil magnesium and fertilizer magnesium uptake by ryegrass on nine mineral soils at two ammonium nitrate levels I. Magnesium uptake. Ann. Agric. Fenn. 20: 000-000. (in press)

- 1981 b. Soil magnesium and fertilizer magnesium uptake by ryegrass on nine mineral soils at two ammonium nitrate levels II. Magnesium content of soils. Ann. Agric. Fenn. 20: 000-000. (in press)

JUO, A. S. R. \& UZU, F. O. 1977. Liming and nutrient interactions in two ultisols from southern Nigeria. Plant and Soil 47: 419-430.

KAILA, A. 1974. Effect of liming on basic exchangeable cations of soil. J. Scient. Agric. Soc. Finl. 46: 167174.

- \& KETTUNEN, H. 1973. Magnesium-supplying power of some Finnish mineral soils. J. Scient. Agric. Soc. Finl. 45: 319-324.

KERÄNEN, T. \& JOKINEN, R. 1964. Magnesiumin puutteen torjuminen magnesiumpitotsuudeitaan erilaisilla kalkkikivijauheilla. Referat: Bekämpfung von Magnesiummangel mit Kalksteinmehlen verschiedenen Magnesiumgehaltes. Ann. Agric. Fenn. 3: 244-255.

KINNIBURGH, D. G., JACKSON, M. L. \& SYERS, J. K. 1976. Adsorption of alkalinen earth, transition, and heavy metal cations by hydrous oxide gels of iron and aluminium. Soil. Sci. Soc. Amer. J. 40: 796799.

MOKWUNYE, A. U. \& MELSTED, S. W. 1973. Magnesium fixation and release in soils of temperate and tropical origins. Soil Sci. 116: 359-362.

MUNNS, D. N. \& FOX, R. L. 1976. Depression of legume growth by liming. Plant and Soil 45: 701-705.

MÄNTYLAHTI, V. \& YLÄRANTA, T. 1980. The estimation of soil lime requirement in soil testing. Ann. Agric. Fenn. 19: 92-99.

TAYLOR, A. W., GURNEY, E. L. \& FRAZIER, A. W. 1965. Precipitation of phosphate from ammonium phosphate solutions by iron oxide and aluminium hydroxide. Soil Sci. Soc. Amer. Proc. 29: 317-320.

VELEZ, J., ZANTUA, M. I. \& BLUE, W. G. 1974. Lime induced plant growth depression in an alluvial entisol from Costa Rica. Soil Sci. Soc. Amer. Proc. 38: 460-464.

WELTE, E., WERNER, W. \& NIEDERBUDDE, E. A. 1960. Zur Frage der Magnesium-Dynamik im Boden. Trans. 7th Int. Congr. Soil Sci. II: 246-252.

WIKLANDER, L. 1960. Influence of liming on adsorption and desorption of cations in soils. Trans. 7th Int. Congr. Soil Sci. II: 283-291.

Ms received April 27, 1981

\section{SELOSTUS}

\section{Kalkituksen vaikutus eräiden kivennäismaiden magnesiumtilaan ja lannoituksena annettuun magnesiumiin}

\section{Raili Jokinen}

Helsingin yliopisto, Maanviljelyskemian laitos, 00710 Helsinki 71.

Tutkimuksen tarkoituksena oli selvittāä $\mathrm{CaCO}_{3}$ :na (lab. reag.) annetun kalkituksen vaikutusta yhdeksän kivennäismaan ( $\mathrm{pH}$ 3,9-6,1) magnesiumtilaan ja lannoituksena annetun magnesiumin kohtaloon näissã maissa. Maat käsiteltiin kalkilla ja magnesiumsulfaatilla $\left(\mathrm{MgSO}_{4} \cdot 7 \mathrm{H}_{2} \mathrm{O}\right)$, joissa maihin lisättiin kalsiumia ja magnesiumia $100 \mathrm{~g}$ maata kohti seuraavat määrăt:

$$
\begin{array}{ll}
\mathrm{Ca}_{0} \mathrm{Mg}_{0} & \text { Ilman Ca ja } \mathrm{Mg} \\
\mathrm{Ca}_{0} \mathrm{Mg}_{1} & \text { Ilman Ca }+4 \mathrm{mg} \mathrm{Mg} \\
\mathrm{Ca}_{1} \mathrm{Mg}_{0} & 90,180 \text { tai } 360 \mathrm{mg} \mathrm{Ca} \\
\mathrm{Ca}_{1} \mathrm{Mg}_{1} & 90,180 \text { tai } 360 \mathrm{mg} \mathrm{Ca}+4 \mathrm{mg} \mathrm{Mg}
\end{array}
$$


Tavoitteena oli kohottaa maiden $\mathrm{pH}\left(\mathrm{CaCl}_{2}\right) 6$ ja 6,5 välille. Sen vuoksi käytetyt kalkkimäärät olivat erilaiset eri maille. Hehtaaria kohti laskettuna magnesiumlannoitus vastaa $80 \mathrm{~kg} \mathrm{Mg}$ ja kalkitukset 5,10 tai 20 tonnia kalkkikivijauhetta ( $35 \%$ neutraloivaa Ca). Maita muhitettiin laboratoriossa aerobeissa oloissa $20{ }^{\circ} \mathrm{C}$ vakiolämpötilassa seitsemän viikon ajan.

Muhitettujen maiden magnesiumpitoisuus määritettiin kolmesta uutteesta

1) $1 \mathrm{M}$ ammoniumasetaatti, $\mathrm{pH} 7$

2) 1 M kaliumkloridi

3) $0,01 \mathrm{M}$ kalsiumkloridi

Kansainvälisissã tutkimuksissa kãytetãān yleisesti neutraalia ammoniumasetaattia vaihtuvan magnesiumin uuttamiseen maasta. Puskuroimaton kaliumkloridi uuttaa maan omassa $\mathrm{pH}$ :ssa vaihtuvana olevaa magnesiumia. Kalsiumkloridiin uuttuva magnesium kuvaa magnesiumin aktiivisuutta (helposti kasvien käytettävissä olevaa magnesiumia).

Seitsemãssã maassa kalkitus nãytti vähentävän $0,01 \mathrm{M}$ kalsiumkloridiin uuttuvan magnesiumin mãäräã enemmān kuin $1 \mathrm{M}$ kaliumkloridiin tai $1 \mathrm{M}$ neutraaliin ammoniumasetaattiin uuttuvaa magnesiumia.

Kalkitut maat sisälsivät ammoniumasetaattiin uuttuvaa magnesiumia $2-24 \%$ vähemmän kuin kalkitsunattomat maat. Magnesiumpitoisuuden väheneminen oli runsainta happamissa liejuisessa hiesussa (Litorina maa) ja hiesusavessa. Kalkitsemattomana nämã maat sisälsivät 6,6 ja $2,2 \mathrm{me} / 100 \mathrm{~g}$ maata $1 \mathrm{M}$ kaliumkloridiin uuttuvaa $(\mathrm{Al}+\mathrm{HF})$ ja niiden $\mathrm{pH}\left(\mathrm{CaCl}_{2}\right)$ olivat vastaavasti 3,9 ja 4,5. Karkeissa hiedoissa kalkitus nãytti lisäävãn ammoniumasetaattiin uuttuvaa magnesiumia, mutta lisãys ei ollut merkitsevã.

Efektiivisen kationinvaihtokapasiteetin suhteellinen lisääntyminen kalkituksen seurauksena saattoi olla karkeissa kivennäismaissa suurempi kuin savimaissa.

Lannoituksena annetusta magnesiumista oli kalkituissa maissa kalsiumkloridiin uuttuvana $17-73 \%$, kaliumkloridiin uuttuvana $67-100 \%$ ja ammoniumasetaattiin uuttuvana $57-100 \%$.

Vaihtuvan ( $\mathrm{pH} 7$ ) kalsiumin ja magnesiumin ekvivalenttisuhde $\mathrm{Ca} / \mathrm{Mg}$ antanee viitteitä kalkitusaineen valintaa varten. Kalkitusaineen tulisi sisältää sitä enemmän magnesiumia mitä korkeampi $\mathrm{Ca} / \mathrm{Mg}$ on maassa. Ihanteelliseksi $\mathrm{Ca} / \mathrm{Mg}$ :n arvoksi on tässã tutkimuksessa otettu useiden tutkijoiden mainitsemat luvut $5-8$. 